La Revista Panamericana de Salud Pública/Pan American Journal of Public Health se complace en publicar cartas de los lectores dirigidas a estimular el diálogo sobre los diversos aspectos de la salud pública en las Américas, así como a esclarecer, discutir o comentar de manera constructiva las ideas expuestas en la revista. Las cartas deben estar firmadas por el autor y especificar su afiliación profesional y dirección postal. Cuando se trate de comentarios sobre un artículo que requieran contestación del autor, se procurará conseguir esa respuesta con el fin de publicar ambas cartas. La Redacción se reserva el derecho de editar las cartas recibidas y resumirlas para mayor claridad.

The Revista Panamericana de Salud Pública/Pan American Journal of Public Health publishes letters from readers for the purpose of stimulating dialogue on various aspects of public health in the Americas and of constructively clarifying, discussing, and critiquing the ideas expressed throughout its pages. Letters should be signed by the author and include his or her professional affiliation and mailing address. If a commentary on a given article requires a reply from the author, an effort will be made to obtain the reply and to publish both letters. The editorial team reserves the right to edit all letters received and to condense them so as to improve their clarity.

\section{OUTBREAK OF HAFF DISEASE IN THE BRAZILIAN AMAZON}

Haff disease, first reported along the Baltic coast in 1924, is unexplained rhabdomyolysis in a person who ate fish in the 24 hours before onset of illness (1). Outbreaks resembling Haff disease were described in Sweden and the Soviet Union between 1934 and 1984 $(2,3)$. In the United States, only three reports have been published to date (4). Haff disease remains a rare clinical syndrome for which there is no physiologic explanation.

Outbreaks of Haff disease have never been reported in Brazil. But in June 2008, a 39-year-old female medical doctor was admitted by the emergency service of a public hospital in Manaus, Amazonas State, Brazil, with diffuse myalgia and chest pain. The plasma creatine kinase (CK) activity levels were 6252 units per liter (U/L) and no history of classic risk factors for rhabdomyolysis was detected. Her mother had been admitted 1 week before, presenting the same symptoms. Both women reported eating fish 24 hours before the onset of symptoms; further inquiry revealed that two residents from the same household who had not eaten fish did not become sick.

The attending physician at the hospital was intrigued by the diagnosis of the two familial cases of Haff disease and began an epidemiologic investigation, looking for similar cases and potential risk factors. A case report form was designed and distributed along with a technical note to all hospitals in Manaus, instructions on how to report suspected cases, and suggestions for their management. The cases were defined as those who were hospitalized on or after 1 June 2008 with a diffuse myalgia of sudden onset who ate fish in the 24 hours before onset of illness and CK serum activity that exceeded five times the upper limit of normal. Patients with a classic risk factor for rhabdomyolysis were not included. The results of the investigation are reported here.

Twenty-five cases of Haff disease were identified in Manaus between June and September 2008. All reported consumption of fried or roasted pacu-silver dollars (Mylossoma spp.), tambaqui-black-finned colossoma (Colossoma macropomum), or pirapitingafreshwater pompano (Piaractus brachypomus), three river fishes of the region, within 24 hours before the onset of symptoms. All patients were older than 13 years of age (range 13-80 years); there were a similar number of males and females $(59 \%$ and $41 \%$, respectively). Three patients came from rural areas surrounding Manaus and nine patients were clustered in four families: the initial mother-daughter pair, a brother-sister pair, a husband-wife pair, and a family of three (husband, wife, and daughter). Five other members of these four families, who did not eat fish, did not fall ill.

All patients were hospitalized (range 3-6 days) with myalgia of sudden onset, mostly localized at the beginning of symptoms and followed by generalized 
TABLE 1. Symptoms of Haff disease cases, Amazon, Brazil, 2008

\begin{tabular}{lcc}
\hline Symptom $(n=27)$ & Number of reports & $\%$ \\
\hline Myalgia & 27 & 100 \\
Chest pain & 19 & 70.4 \\
Neck pain & 17 & 62.9 \\
Muscular stiffness & 13 & 48.1 \\
Pain upon light touch & 12 & 44.4 \\
Weakness & 11 & 40.7 \\
Nausea & 11 & 40.7 \\
Muscle contracture & 10 & 37 \\
Dark urine & 9 & 33.3 \\
Vomiting & 9 & 33.3 \\
Malaise & 8 & 29.6 \\
Diarrhea & 4 & 14.8 \\
\hline
\end{tabular}

spreading within a few hours. Nineteen patients reported chest pain, among other symptoms (see Table 1). No fever or kidney damage was observed.

Predominant laboratory abnormalities were elevated CK serum activity (mean $=12795 \mathrm{U} / \mathrm{L}$, range 1 444-36 896 U/L). Serum activities of transaminases and lactate dehydrogenase were also elevated. In two patients, myoglobin was measured and found to be higher than $700 \mathrm{U} / \mathrm{L}$. Serology for leptospirosis and hepatitis A and B was negative. Patients were treated with intravenous fluid hydration and bicarbonate infusion. No deaths were observed.

In only 4 months, 27 cases of Haff disease were reported in Manaus and surrounding municipalities of the Brazilian Amazon. The diagnosis of Haff disease was made based on the fact that none of the cases could be explained by classic causes of rhabdomyolysis; all patients reported consumption of fish within 24 hours before the onset of symptoms; some cases occurred in family clusters and no cases were observed after the beginning of the period of prohibition of fishing in the region that occurs every year from October to March. This possible association between fish eating and rhabdomyolysis in the Amazon region may have an important impact, as fish is a major source of protein in the Brazilian Amazon (5). Active surveillance of this supposedly uncommon condition is necessary to corroborate its frequency in the region and enhance our understanding of this elusive disease.

This paper is part of the doctoral thesis of Marcelo Cordeiro dos Santos of Amazonas State University, Amazonas State Tropical Medicine Foundation.

The views expressed here are those of the authors and do not necessarily reflect the official policy or position of the Brazilian Government, the U.S. Gov- ernment, Department of the Navy, or Department of Defense.

Marcelo Cordeiro dos Santos

Universidade do Estado do Amazonas

Fundação de Medicina Tropical do Amazonas

Fundação de Vigilância em Saúde

Centro Universitário Nilton Lins

Manaus, Amazonas, Brazil

Phone/fax: 559232381718

E-mail: marcelo_cordeiro@uol.com.br

Bernardino Claudio de Albuquerque

Fundação de Vigilância em Saúde

Manaus, Amazonas, Brazil

Rosemary Costa Pinto

Fundação de Vigilância em Saúde

Centro Universitário Nilton Lins

Manaus, Amazonas, Brazil

Giralcina Pessoa Aguiar

Fundação de Vigilância em Saúde

Manaus, Amazonas, Brazil

Andres G. Lescano

U.S. Naval Medical Research Center Detachment Universidad Peruana Cayetano Heredia

Lima, Peru

João Hugo Abdalla Santos

Fundação de Medicina Tropical do Amazonas Manaus, Amazonas, Brazil

Maria das Graças Costa Alecrim

Universidade do Estado do Amazonas

Fundação de Medicina Tropical do Amazonas

Centro Universitário Nilton Lins

Manaus, Amazonas, Brazil

\section{REFERENCES}

1. Zu Jeddeloh B. Haffkrankheit. Ergeb Inn Med Kinderheilkd. 1939;57:138-82.

2. Buchholz U, Mouzin E, Dickey R, Moolenaar R, Sass N, Mascola L. Haff disease: from the Baltic Sea to the US shore. Emerg Infect Dis. 2000;6:192-5.

3. Berlin R. Haff disease in Sweden. Acta Med Scand. 1948;129: 560-72.

4. Langley RL, Bobbitt WH III. Haff disease after eating salmon. South Med J. 2007;100(11):1147-50.

5. Ministério da Integração Nacional, Brasil. Relatório do censo estrutural da pesca de águas continentais da região norte. Brasilia; Ministério da Integração Nacional: 2006. 